\title{
Mirroring the Subtext: Postmodernism in Ngugi wa Thiongo's Wizard of the Crow.
}

\author{
Oscar M. Maina
}

This reading of Ngugi wa Thiong'o's Wizard of the Crow attempts to place the text in the postmodern writing tradition. We point out how surrealistic features are utilized to enhance the themes, style, and the author's conundrums. Ngugi has been accused of focusing on ideologies at the expense of creativity. Wizard of the Crow is, however, a purely artistic text where Ngugi's creativity is plausibly developed, without hindering his ideological expression. The fact that the text was originally written in Gikuyu helps the writer draw from the resource of traditional discourse, and arguably enable not only Gikuyu culture, but also their worldview and history negotiate for a global position in line with emerging postmodern imperatives.

As a creative method, postmodernism nurtures and nourishes our interrogation of human and artistic possibilities. This creative method, according to Roman Jakobson, enhances the "supremacy of poetic function over referential function" without obliterating the reference, but by making it ambiguous. Jakobson reminds us that, "ambiguity is an intrinsic, inalienable character of any self-focused message" (48). This is more aptly explained by the fact that reality does not always mediate between text and meaning, but lets the reader rescue or recover the rest of the meaning from their subjective perspective.

But what exactly is postmodernism? This artistic method stems from shifts in cultural, philosophical and artistic principles and methods. In literature and literary theory, postmodernism gained currency in the 1950's though the path of its development can be traced from realism through modernism.

This creative method has had its share of criticism. For instance, Tzvetan Todorov is of the opinion that postmodernism, "expresses the idea of progress in its most naïve form, one that would like everything coming after to be better than everything that came before" (2). Todorov accuses postmodernism of celebrating ambiguity and incoherence, in its preference for the term 'postmodernism'. However, the pessimism expressed by modernist writers would have divorced art from human consciousness. Amidst the chaos of the postmodern society, creativity should as Ben Okri suggests, be functional to the human consciousness. This would heal the human spirit by giving back to it, "its full, rich, hidden dimensions", meaning that postmodernism is an artistic improvement on modernism, regardless of the term of choice.

For our current purpose, it is imperative that we acquaint ourselves with the predecessors of postmodernism: realism and modernism. Realism, on its part, attempts a comprehensive interpretation and description of a society. By using the resources of this method, writers seek not only to describe the world (a construction of social forces), but also to reflect an objective reality that is shaped by human will and actions. Modernism on the other hand faults the very core of realism. The argument in this 
case is that realism assumes, in its claim of the possibility of availing a comprehensive representation of reality, that reality is a linear, express result of cause and effect. The modernist therefore scuttles the assumption that there exists an objective reality, which can be adequately perceived by a writer and represented in a text. According to the modernist perspective, the world is incomprehensible and in this sense, a writer's mind cannot adequately grasp, leave alone represent the complex social interrelations within the confines of a literary text.

This break from realism is the main contention of modernism. The modernist sees the world from a pessimistic point of view. It is a world that is fragmented, decayed, and largely characterized by chaos. Another distinctive feature of modernism is its pessimistic view of contemporary science and technology, and consequent capital determinants of social interaction and human relations. This revulsion can in part be attributed to the consequences of the First World War as evident in the works of T.S. Eliot and Ezra pound, to mention just the two. Modernist writing, according to Mary Klages, "tends to present a fragmented view of human subjectivity and history"(2). This is the source of modernist pessimism. To the modernist, this fragmentation is tragic, and we should mourn this loss (The Wasteland, Mother Courage and her Children). The role of the artist is therefore defined: to provide unity, meaning and coherence which have been eroded by the modern life.

Conversely, postmodernism has a celebrative attitude towards the modern world. Unlike the modernist who laments and problematizes human identity and individuality, the postmodernist appreciates the overcoming of limitations of human progress, although this progress lacks distinctive direction and purpose. With a particular bias to artistic representation, postmodernism rejects the tragic and pessimistic worldview of modernism. Postmodernism embraces human diversity in culture, art and ideology in a universal context. Relativism and indeterminacy are therefore major characteristics of a postmodern reading of a text, which rejects the concept of a unified underlying reality.

The major premise of postmodernist representation is the fact that creative writing does not simulate, but rather it is its own simulacra or simulation. Art, an integral part of society, should according to the postmodern discourse, seek to wrestle creativity from poetic incarceration, and adopt a populist stance. Art is seen as a populist (not elitist) endeavor that should be taken to its rightful place: to the masses. This could only be achieved if the creative writer adopts the worldview of the masses in terms of their folklore, beliefs, myths and superstitions. The point of departure is the rejection of the distinction between low and high culture and art. The world is destructured and decentred, meaning that human experience is universal.

Another way of looking at modernism and postmodernism would be from Frederic Jameson's assertion that "modernism and postmodernism are cultural formations which accompany particular stages of capitalism" (2). Jameson's definition pays attention to modes of production and technologies, and identifies three phases of capitalism, each with its accompanying cultural practices, art and literature. The first phase is market capitalism, which occurred in the eighteenth and late nineteenth 
century in Europe and the United States. This phase is identified with the steamdriven motor as the major technological development. The significant literary method during this phase is realism. The second phase occurred from late nineteenth to midtwentieth century, and is associated with electric and internal combustion engines, and with modernism as the prominent literary method. The third phase, in which we are living, is the multinational or consumer capitalism where consumption supersedes production. This phase is associated with nuclear and electronic technology and with postmodernism.

For the historian and the sociologist, postmodernism is best defined as a set of social and historical attitudes, and contrasts "postmodernity" with "modernity." How do they differ? Whereas modernism refers to the aesthetic movement of the twentieth century, modernity refers to philosophical, ethical and political ideas that form the aesthetic foundation of modernism. Modernity is more concerned with rationality, order, and the entrenchment of grand narratives (archetypes and prototypes). Postmodernity on the other hand scuttles these grand narratives and in their place advocates for mini-narratives that facilitate the apprehension of situational and local realities. The aesthetic practice is therefore to deconstruct the grand narratives or the epicenter, by rejecting the hegemony of dominant ideological, cultural and social posturing. This explains why postmodernism as a literary method is particularly popular with feminist, oriental and postcolonial writers and thinkers.

It is from this theoretical context that Ngugi's art may be examined. As a writer, Ngugi is subject to socio-economic and ideological imperatives that govern the production and consumption of knowledge and culture. We will examine how Ngugi adheres to the situational and local realities in line with postmodern aesthetics, as well as how global trends affect his art.

As a writer, Ngugi has always focused on the plight of the marginalized, oppressed masses, and Wizard of the Crow is not antagonistic to his earlier texts. Major themes and motifs retain a striking similarity. Ngugi's literary canon maintains uniformity in terms of motifs and umbrella thematic foci. The journey motif is the most prominent. In Wizard of the Crow, this motif is refined in that instances of preternatural flights manifest. In two different instances, Kamiti's spirit leaves his physical body, and he takes a spiritual journey through time and space: "he felt his whole self lighten and he saw himself rise, rise and float, reaching beyond the grasp for Nyawira. He had left his body behind, and now a bird, he was flying freely in the open sky...(494). The song Nyawira sings to Kamiti in his vision punctuates this spiritual journey:

$$
\begin{aligned}
& \text { Wake up brother spirit } \\
& \text { Wake up sister spirit } \\
& \text { If you let sleep rule over you } \\
& \text { Blessings will pass you by. (494) }
\end{aligned}
$$

His flight is a reconnaissance of the African Diaspora: from the pyramids of Egypt to the Caribbean islands. It is a spiritual journey that helps him come to terms with his immediate predicament. In fact Ben Okri, a postmodern writer in his own right, is 
convinced that this art is functional to the human spirit for it can give back to the spirit, "its full, rich, hidden dimensions." By focusing on a society in chaos, postmodern writing helps us explore the futility of human obsessions that are the root cause of social evils and oppression.

From a stylistic angle, Ngugi makes use of a narrating persona who is distinct from the writer- making it possible to transcend the limitations of time and space. This narrator is Arigaigai Gathere, "the teller of tales and not the monger of rumors". This particular technique functions as a tool for psychic and historical exploration, and this is more so when Ngugi, in creating his protagonists, imbue them with his social and literary ideologies. But artistic concerns are more urgent in Wizard of the Crow. In the words of Wole Soyinka, literary works should not only seek to be socially persuasive, but writers should uphold those concerns that go beyond pure narrative, to reveal a reality that goes beyond the "the immediately attainable" (66). This aspect rewards Ngugi's text in that his social vision does not blur his artistic endeavor. The text can be appreciated for the particularly striking metaphorical connotations, most of which are availed by the postmodern art.

Ngugi wa Thiongo's Wizard of the Crow utilizes the resource of magical realism to enhance its interrogation of post-independence leadership in Africa through the fictive Free State of Aburiria. Magical realism, a facet of postmodernism, is described by Olatubasun Ogunsanwo as, "a new yearning and a new discovery that is slowly occupying the old tyranny of the mean description of reality." While eschewing a postcolonial depiction of the Aburirian society, the text does not only invite the reader to share in the comedy of dictatorship, despotism and neoimperialism, but delves deeper to expose "the literary aesthetic of truth telling." This endeavor is made possible by the dynamics of postmodern art, which informs the text's literary wealth, thematic focus, and ideological intimations.

It is apparent throughout the text that Ngugi intends to reflect the plague of a postcolonial society and the manifestations of inherited colonial heritage. Aburiria, a postcolonial society has the misfortune of moving from one oppressive regime (colonialism) to the post-independence dictatorial, despotic rule of the Ruler. Even as the text intimates a postcolonial approach, it embraces the globalized, postmodern culture and global hybridity. Postmodern writing is consistent with postcolonial literature in its attempt to debunk Western narrative archetype and culture. On its part, postcolonial study pays attention to how language "becomes a medium through which a hierarchical structure of power is perpetuated"(7). The postcolonial writer refutes and deconstructs the colonizers hegemonic structures that attempt to monopolize truth, order and reality. It is for this reason that Ngugi remains a vocal critic of our over-reliance on Western languages. In "Homecoming": Address at the University of Nairobi, August 2004, Ngugi argues that in fact, "language as logically connected words is basically a naming system. You name the world and you own the world". The colonizer, in an effort to deny the Africans the memory of their skills, knowledge and experience effectively used linguistic alienation. Ngugi's worry is that "by surrendering to the European naming system, we bury our memory under the European memory"(65). As a producer of ideas, the postcolonial writer should 
remember the African past, and re-member the previously dismembered African reality.

Postmodern writing, as in Ngugi's text, makes intensive use of the writer's cultural past in terms of the choice of the dominant narrative dimension. This narrative dimension is the pillar that organizes the text's thematic, stylistic, and ideological focus. In an apparent postmodern viewpoint, each and every culture has its subjective interpretation of its reality. A postcolonial writer affirms the colonized's history and culture that has been abnegated by the colonizer. In Wizard of the Crow, Ngugi uses African narrative rhythms to authenticate the cultural setting of the text.

Ngugi creates characters that modify strategic body organs in a desperate attempt at making themselves useful to the neoimperial socio-economic and political order. This organismic alteration is symbolic of distorted human values on whose back dictatorship battens. It should be noted that the ascription of these grotesque and surrealistic features serves a stylistic as well as a didactic function. While satirizing the futility of oppressive governance, this presentation paints pictures of detestable characters. The people's reaction to these "modification" is evident in this part of the narrative.

People at the stadium kept comparing their different expressions, particularly the movements of their eyes and ears, for it had long been known that the two were always in a mortal struggle to establish which organ was more powerful. The eye or the ear of the Ruler (14).

Ngugi invites the reader to share in the exploration of the cult of dictatorship, its origin, and also its aftermath. Sycophants like Sikiokuu, Machokali, Tajirika, Kaniuru, and others of the same disposition are the cogs that keep the wheel of dictatorship turning. The people of Aburiria are left to contend with extreme poverty while their rulers batten on their backs. Wole Soyinka (1972) feels that "the cold reality of power is, of course, that it has to be endured"(xiv). Endurance doesn't imply docility, for the man dies in spirit who opts to remain silent. In fact, Tom Brass is of the opinion that, "opposition to existing social order derives not from class formation, class struggle, and the politics of class, but from hitherto undiscovered authentic grassroots voice"(249). It's apparent from Brass' argument that the voice of an oppressed society should nurture the rediscovery of that society's authentic voice. They must challenge passivity and victimhood, for to paraphrase Soyinka, when power is put at the disposal of vicious reaction, a language must be utilized, " which does its best to appropriate such obscenity of power and fling its excesses back in its face" (xiii).

The symbolic meaning of this character depiction is not lost to us. While depicting the reality of a postcolonial state, Ngugi creates characters like Machokali, Big Ben Mambo and Sikiokuu, whose only reality exists within the reality of the narrative. This is an express instance of the postmodern metaphor, and a direct denial of verisimilitude. Our interpretation calls for a greater effort in decoding their nonlinear presentation and interpretation of reality. As Ngugi reminds us, "dictatorship is a tragedy that manifests itself in comedy." The text satirizes these characters' hunger for power and wealth. 
As opposed to this alienating depiction, populist characters are given a more heroic presentation. As Ogude notes, women in particular serve as "allegorical tropes (and) primary sites for testing the reconciliation of ethnicity and hope and, the possibility of a rebirth" (109). As opposed the strain of urban victimhood experienced by women characters such as Wariinga in Devil on the Cross and Wanja in Petals of Blood, Nyawira is in harmony with the city. She is educated and a repository of ideologies that opens up Kamiti's dormant conscience. The metropolitan city is celebrated for its heterogeneity and protective functions, as opposed to the popular depiction of the city as a repository of evil and moral degeneration.

As a salient feature of postmodernism, the text is replete with surrealistic incidents and scenes. Nyawira is for instance described as the source of a sweet smell, a contrast of the stench evident in the streets of Eldares, the capital of Aburiria. She is the source of "a more powerful smell, a fresh one, like the scent of flowers" (50). Nyawira's populist ideology contrasts her with the stinking, capitalistic rottenness that characterizes the streets of Eldares. The ruler's 'self-induced expansion', his floating body; his non- stop speech that lasts for seven days, hours, minutes and seconds, are all only possible in the realm of imaginative, postmodern writing. There is also the Museum of Arrested Motion where objects and animals freeze in motion, and which, "would change colors dramatically, depending on the intensity and angle of the sun"(443).

The contrast between good and evil is captured in the stench that comes from money, as this description points out:

The putrid smell was most intense where the bags of money stood like three guardians of evil stopping him [Kamiti] in his tracks. He felt weak, faint, and held on to a wall." (188)

These surreal descriptions serve a didactic function. They add to the narrative literary wealth that abstract descriptions would erode. In this way, postmodernism enhances the stylistic as well as the didactic flavor of the text, and as in oral narratives, these features are condensed stylistic and literary statements communicated in a covert manner. When Tajirika, the Ruler and Sikiokuu develop a mouth at the back of their heads, we are reminded of ogres in oral narratives. This displacement serves to punctuate the greed of post-independence leadership, while asserting the African narrative tradition.

A primary metaphor in Wizard of the Crow is the wizard. Kamiti, the wizard of the crow, is pivotal both in presentation and in practice of the craft. He is the embodiment of the writer in a postcolonial, neoimperial state. The act of mirroring is akin to the role of a writer who reflects the evils of those in power, and also helps the society voice its most obscene thoughts and desires. The alienated elite like Tajirika, Sikiokuu, and the Ruler suffer from the malady of words. The word "if" gets stuck in their throats, and it is only the wizard, who can help them confront their most obscene desire: to become white. In Detained, Ngugi points out the role of the writer, and hints at the perilous nature of the calling: "for I have accepted the lot of all writers who try 
to hold a clear mirror unto the motions of human thought, human society and history in general"(190-1). The text in calling for the services of postmodernism transcends with magnificent ease between realism and hyperrealism. The writer serves to reflect, just like a mirror, what goes on in the society. It is this art that predisposes the writer, herein read as the wizard, to all manner of tribulations. The writer has dual power: to reflect the evil of the ruling class, and to reach out to the masses and shape their conscience. Writing is thus the shrine to which people come to savor their images as divined by the writer-wizard.

Postmodernism celebrates human diversity in culture, art and ideology. As a 'writer' and diviner, Kamiti advocates for a syncretic view of Indian and African history. Mahatma Gandhi serves as Kamiti's impetus for his revolutionary and spiritual growth. In a momentous nirvana, Kamiti evaluates the significance of "the prophets of old, Confucius, Gautama Buddha, Moses, John the Baptist, Mugo wa Kibiru, who had all retreated into the wilderness to commune, in total silence, with the law and that held the universe together" $(47)$. The collocation of these prophets is an example of postmodern "mixing" which, according to Mikhail Gromov, "leads to a postmodernistic mixture of styles, which in wider sense is known as 'intertextuality'"(29). It is an attempt at universalizing human culture and negotiating for the relevance of African prophetic figures and history, and in the same breath remembering African heroes in their heroic past.

Though Ngugi's text draws much of its mimetic power from the African political experience, it reveals a universal human condition. Human beings have an insatiable desire for power and wealth. We are ready to engage evil in a bid to secure for ourselves the comfort of luxury and power. This is a universal trait handed down over generations through the premise of capitalist modernity.

In essence, Wizard of the Crow decries human impunity, and privileges acts of humane charity. The punishment that is meted out on the ruler and his pack of aristocrats serves to underscore the temporal nature of material things. Nyawira and Kamiti are rewarded with life and an indefinite union. This underscores the novel's moralphilosophical didactics: illicit power and wealth are ephemeral and brittle for they melt away with time.

Ngugi emphasizes the importance of retaining the memory of our historical identity. Knowing who we are is not enough; we should also be conscious of where we are coming from. This would help us, the post-colonials, avoid mistakes that have turned heroes and heroines who struggled for our liberty villains of their own sacrifice.

Wizard of the Crow makes good use of the texture of African speech rhythms. Though the text has been translated from the Gikuyu language, it retains much of its original structures. Ngugi's own translation deliberately leaves intact the flowing yet loaded African folkloric constructions. The novel does not restrict itself to the conventional grammatical structures, and this preserves its African flavor. This undoubtedly gives the text its postcolonial identity, which is intricately tied to its postmodern appeal. 
Postmodernism and postcolonialism share in not only the way they refute Eurocentric conventions, but also in their use of history as key to the creative process.

\section{References}

Ashcroft, Bill et al.( 2004). The Empire Writes Back. New York: Routledge.

Jakobsn, Roman.( 2004). "Linguistics and Poetics." Modern Criticism and Theory. (second edition) ed. David Lodge. Delhi: Pearson.

Jameson, Fredric. (2004). "The Politics of Theory: Ideological Positions in the Postmodernism Debate." Modern Criticism and Theory. (second edition) ed. David Lodge. Delhi: Pearson.

Klages, Mary. "Literary Theory: A Guide for the Perplexed." http://www. Colorado.edu/ English/Courses/ ENGL2012Klages/ pomo.html

Ngugi wa Thiong'o .(2007). Wizard of the Crow. Nairobi: E.A.E.P.

Ngugi wa Thiong'o, (1981). Detained: A Writer's Prison Diary. Nairobi: Heinemann.

Ngugi wa Thiong'o. (2005)."Homecoming: Address at the University of Nairobi." In Nairobi Journal of Literature.

Ogude, James. (1999).Ngugi's Novels and African History: Narrating the Nation. London: Pluto.

Soyinka, Wole. (1976). Myth, Literature, and the African World. New York: Cambridge.

Soyinka, Wole. (1972). The Man Died. London: Rex Collins.

Todorov, Tzvetan. (2007). "Postmodern Culture: Introduction to the Theories of the Contemporary" Electronic Journal. 